\title{
Biogeography and taxonomy of Apodemus sylvaticus (the woodmouse) in the Tyrrhenian region: enzymatic variations and mitochondrial DNA restriction pattern analysis
}

\author{
J. R. MICHAUX*, M.-G. FILIPPUCCI $\$$, R. M. LIBOIS, R. FONS $\ddagger$ \& R. F. MATAGNE \\ Service d'Ethologie et de Psychologie Animale, Institut de Zoologie, Quai Van Beneden 22, 4020 Liège, Belgium, \\ $\dagger$ Dipartimento di Biologia, Universita di Roma 'Tor Vergata', Via O. Raimondo, Rome 00173, Italy, $\ddagger$ Centre d'Ecologie \\ Terrestre, Laboratoire ARAGO, Université Paris VI, 66650, Banyuls/Mer, France and \$Laboratoire de Génétique des \\ Microorganismes, Institut de Botanique (Bat. B 22), Université de Liège, Sart Tilman, 4000 Liège, Belgium
}

\begin{abstract}
In the western Mediterranean area, the taxonomic status of the various forms of Apodemus sylvaticus is quite unclear. Moreover, though anthropogenic, the origins of the island populations remain unknown in geographical terms. In order to examine the level of genetic relatedness of insular and continental woodmice, 258 animals were caught in 24 localities distributed in Belgium, France, mainland Italy, Sardinia, Corsica and Elba. Electrophoresis of 33 allozymes and mtDNA restriction fragments were performed and a UPGMA dendrogram built from the indices of genetic divergence. The dendrogram based on restriction patterns shows two main groups: 'Tyrrhenian', comprising all the Italian and Corsican animals and 'Northwestern', corresponding to all the other mice trapped from the Pyrenees to Belgium. Since all the Tyrrhenian mice are similar and well isolated from their relatives living on the western edge of the Alpine chain, they must share a common origin. The insular populations are consequently derived from peninsular Italian ones. From a taxonomic point of view and taking the priority rules into account, we have to invalidate $A$. s. clanceyi Harrison, 1948 and to consider the Tyrrhenian woodmice as belonging to $A$. s. milleri de Beaux, 1926, whereas the North-western ones must be referred to as the nominal subspecies. As far as the Elban woodmouse is concerned, at the moment we prefer to keep its present subspecific status because we only studied one animal.
\end{abstract}

Keywords: allozymes, Apodemus sylvaticus, biogeography, Italy, mitochondrial DNA, taxonomy.

\section{Introduction}

Despite several morphological studies (Kahmann, 1969; Pasquier, 1974; Darviche, 1978; Filippucci et al., 1984; Alcover \& Gosalbez, 1988; Kowalski \& Rzebik-Kowalska, 1991; Libois et al., 1993; Sara \& Casamento, 1995) and a general revision of the genus Apodemus throughout France (Saint Girons, 1966, 1967), the subspecific status of the various Mediterranean woodmouse populations remains unclear.

In continental western Europe, four subspecies are currently considered (Toschi \& Lanza, 1965;

${ }^{*}$ Correspondence.

(C)1996 The Genetical Society of Great Britain.
Saint Girons, 1973). Apodemus sylvaticus sylvaticus (L., 1758) is the most widespread in an area delimited by the Pyrenees and the Alps and whose northern limit reaches Scandinavia and the British Isles (mainland Ireland and U.K.) dichrurus (Rafinesque, 1814) is viewed as the 'Mediterranean' subspecies inhabiting Sicily (Locus typicus), Sardinia, Corsica, southern Italy, southern France and Spain. The range of $A$. s. callipides (Cabrera, 1907) includes the Cantabric and the Pyrenean chains and extends towards the Massif Central. milleri de Beaux, 1926 (= clanceyi Harrison, 1948) is restricted to northern and central Italy. Moreover, numerous insular populations have received subspecific status because of their large size or cranial differences, for example in 
the Hebrides and Shetlands (Berry et al., 1967; Berry, 1973; Flowerdew, 1991) but also in the Mediterranean area: $A$. s. hermani (Felten \& Storch, 1970) on the Pantelleria island, $A$. s. ilvanus Kahmann \& Niethammer, 1971 on Elba, A. s. eivissensis (Alcover \& Gosalbez, 1988) on Ibiza.

The boundaries of the geographical areas of the mainland subspecies are still confusing and cannot be interpreted easily because they do not correspond to any obvious geographical barrier. For example, in the eastern Pyrenees, it is quite impossible to draw any ecological or geographical limit between the two forms supposed to live there: in suitable habitats, the woodmouse is present everywhere, from the coast to the subalpine bushes (Fons et al., 1980; Libois et al., 1983). Moreover, the woodmice of Elba, Sardinia and Sicily were found to be genetically very close to those of peninsular Italy (Filippucci, 1987, 1992) although the populations of Sicily were considered by Von Lehmann \& Schaefer (1976) to be very different and were assigned to a separate species, $A$. dichrurus Rafinesque, 1814. Finally, there is archaezoological evidence that the woodmouse was not present in Corsica and Sardinia until the beginning of the third millennium $\mathrm{BC}$ and the anthropogenic origin of its presence is taken for granted (Sanges \& Alcover, 1980; Vigne, 1983).

The origins of the woodmouse populations on the different islands are important to determine if we are to achieve a better understanding of the biogeography of the species in the western Mediterranean basin. In this article, we report an overall genetic comparison of different woodmice populations living in that area. In Mus musculus domesticus (the house mouse), very important karyotypic differences are observed, even in restricted geographical areas (Said \& Britton-Davidian, 1991; Searle, 1991; Mathias, 1992). No such differences have ever been discovered among $A$. sylvaticus populations. Moreover, the karyotype and the $\mathrm{G}$ and Q-banding patterns of the woodmouse are very similar to those of $A$. flavicollis (the yellow-necked mouse) (Engel et al., 1973). However, Giagia (1985) reports some rare individuals bearing supernumerary acrocentric chromosomes whose significance remains unclear, their occurrence being higher in polluted areas (caused by heavy metals and chemicals). Consequently, karyotypic techniques do not appear well suited to our study. Two molecular techniques were thus applied: an electrophoretic analysis of allozymes and a study of mtDNA variation. The first technique allowed us to compare our results with those of Filippucci $(1987,1992)$ whereas the second, which is far more sensitive because of the fast evolu- tionary rate of mtDNA (Brown, 1980; Ferris et al., 1983a; Wilson et al., 1985; Moritz et al., 1987), gave us data we could compare with those of Tegelström \& Jaarola (1989) and Van Rompaey (1989).

\section{Materials and methods}

Biochemical and mitochondrial DNA analyses were performed on specimens representing a total of 24 wild populations from Belgium, France, Italy and also three Mediterranean islands (Sardinia, Corsica and Elba). The animals were trapped alive with 'Manufrance' traps. The sampling localities are presented in Table 1 and Fig. 1.

\section{Electrophoretic analysis of allozyme variation}

Electrophoresis was carried out using tissues from 191 animals (Table 1). Tissues were maintained at $-80^{\circ} \mathrm{C}$ until processed. Homogenates were obtained from pieces of muscle tissue for electrophoresis and screened for the following alloenzymes using the methods of Filippucci et al. (1984) and Filippucci (1992): $\alpha$-glycerophosphate dehydrogenase (EC 1.1.1.8; $\alpha-G p d h)$, lactate dehydrogenase (EC 1.1.1.27; $L d h-1$ and $L d h-2)$, malate dehydrogenase (EC 1.1.1.37; $M d h-1$ and $M d h-2$ ), malic enzyme (EC 1.1.1.40; $\mathrm{Me}-1$ and $\mathrm{Me}$-2), isocitrate dehydrogenase (EC 1.1.1.42; Idh-1 and Idh-2), 6-phosphogluconate dehydrogenase (EC 1.1.1.44; 6-Pgdh), glucose6-phosphate dehydrogenase (EC 1.1.1.49; G6pdh), glyceraldehyde-3-phosphate dehydrogenase (EC 1.1.212; G3pdh), indophenol oxidase (EC 1.15.1.1; Ipo-1 and Ipo-2), nucleoside phosphorylase (EC 2.4.2.1; $N p$ ), glutamic-oxaloacetic transaminase (EC 2.6.1.1; Got-1 and Got-2), hexokinase (EC 2.7.1.1; $H k-1$ and $H k-2$ ), creatine kinase (EC 2.7.3.2; Ck), adenylate kinase (EC 2.7.4.3; $A d k$ ), esterase (EC 3.1.1.1; Est-3), acid phosphatase (EC 3.1.3.2; Acph), leucyl aminopeptidase (EC 3.4.11.1; Lap), aminopeptidase (EC 3.4.11.11; $A p-2$ and $A p-3$ ) adenosine deaminase (EC 3.5.4.4; $A d a$ ), aldolase (EC 4.1.2.13; Aldo), fumarate hydratase (EC 4.2.1.2; Fum), mannose-6-phosphate isomerase (EC 5.3.1.8; Mpi), glucose-6-phosphate isomerase (EC 5.3.1.9; Gpi), phosphoglucomutase (EC 5.4.2.2; Pgm-1 and Pgm-2).

Isozymes were numbered in order of decreasing mobility from the most anodal band. Allozymes were numbered according to their mobility, relative to the most common allele $(=100)$ in the population of Burano (Nascetti \& Filippucci, 1984) $(<100=$ slower mobility; $>100=$ faster mobility $)$. Allozymic data were analysed as allele frequencies 
Table 1 Sampling localities and number of Apodemus sylvaticus processed by each technique

\begin{tabular}{|c|c|c|c|c|}
\hline Locality & $\begin{array}{c}\text { Total } \\
\text { no. of } \\
\text { animals }\end{array}$ & $\begin{array}{l}\text { No. of animals } \\
\text { (allozyme } \\
\text { analysis) }\end{array}$ & $\begin{array}{l}\text { No. of animals } \\
\text { (mtDNA } \\
\text { analysis) }\end{array}$ & $\begin{array}{c}\text { Sample } \\
\text { symbols } \\
\text { (see Fig. 1) }\end{array}$ \\
\hline \multicolumn{5}{|l|}{ Belgium } \\
\hline Sart Tilman & 9 & 9 & 6 & B1 \\
\hline Héron & 3 & 0 & 3 & B2 \\
\hline Seilles & 5 & 0 & 5 & B3 \\
\hline Namur & 8 & 3 & 8 & B4 \\
\hline \multicolumn{5}{|l|}{ Italy } \\
\hline Tarquinia, Latium & 31 & 21 & 31 & I1 \\
\hline Grosseto, Tuscany & 4 & 4 & 4 & $\mathrm{I} 2$ \\
\hline San Polo dei cavalieri, Latium & 6 & 6 & 0 & I3 \\
\hline Burano lake, Tuscany & 91 & 91 & 0 & I4 \\
\hline Gambarie, Calabria & 5 & 0 & 5 & I5 \\
\hline Cuneo, Piedmont & 1 & 0 & 1 & I6 \\
\hline \multicolumn{5}{|l|}{ Sardinia } \\
\hline Pietru & 6 & 1 & 6 & S1 \\
\hline San Antonio & 1 & 0 & 1 & S2 \\
\hline P. Tricoli & 7 & 7 & 0 & S3 \\
\hline \multicolumn{5}{|l|}{ Elba } \\
\hline Monte Perone & 13 & 12 & 1 & E1 \\
\hline \multicolumn{5}{|l|}{ Corsica } \\
\hline Fango (river) & 10 & 10 & 10 & $\mathrm{C} 1$ \\
\hline Fango (mouth) & 7 & 7 & 7 & $\mathrm{C} 2$ \\
\hline Chiuni & 1 & 1 & 1 & $\mathrm{C} 3$ \\
\hline \multicolumn{5}{|l|}{ France } \\
\hline Cap Lardier & 7 & 7 & 7 & F1 \\
\hline Banyuls/Mer & 12 & 12 & 6 & $\mathbf{F} 2$ \\
\hline Massane & 8 & 0 & 8 & F3 \\
\hline Mont Vinaigre & 4 & 0 & 4 & F4 \\
\hline La Penne & 6 & 0 & 6 & F5 \\
\hline St Brisson & 11 & 0 & 11 & F6 \\
\hline Menigoute & 2 & 0 & 2 & F7 \\
\hline
\end{tabular}

with the BIOSYS-1 program of Swofford \& Selander (1981). Intrapopulational genetic variation was estimated by the mean heterozygosity per locus $\left(H_{\mathrm{e}}=\right.$ expected frequency of heterozygotes under a Hardy-Weinberg equilibrium; Nei, 1978), proportion of polymorphic loci in the population $\left(P_{0.01}\right.$, i.e. a locus is considered as polymorphic if the frequency of the common allele is not greater than 0.99), and the mean number of alleles per locus $(A)$. The level of genetic divergence between populations was estimated using the indices of standard genetic identity $(I)$ and distance $(D)$ proposed by Nei (1978).

\section{Mitochondrial DNA restriction pattern analysis}

Mitochondria were isolated from fresh or frozen (liquid $\mathrm{N}_{2}$ ) liver, heart, spleen and kidney according to Lansman et al. (1981). mtDNA was isolated using the method of Palva \& Palva (1985) and then digested with restriction enzymes. In each case, $1-3 \mu \mathrm{L}$ mtDNA solution containing $20-40$ ng DNA were used. Two types of tetranucleotide restriction endonucleases (Boehringer Mannheim or BRL) were utilized: HaeIII (GGCC) and RsaI (GTAC). Digests were carried out for $1-2 \mathrm{~h}$ in $10 \mu \mathrm{L}$ reaction liquid containing one enzyme unit. The mtDNA fragments were separated in 4 per cent PAA gels according to Tegelström (1986) and revealed by the silver staining protocol of Guillemette \& Lewis (1983). All distinctive mtDNA restriction fragment patterns produced by HaeIII were assigned a letter. Restriction fragment patterns produced by $R s a \mathrm{I}$ were assigned a number. Each animal was thus assigned a letter and a number. All specimens 


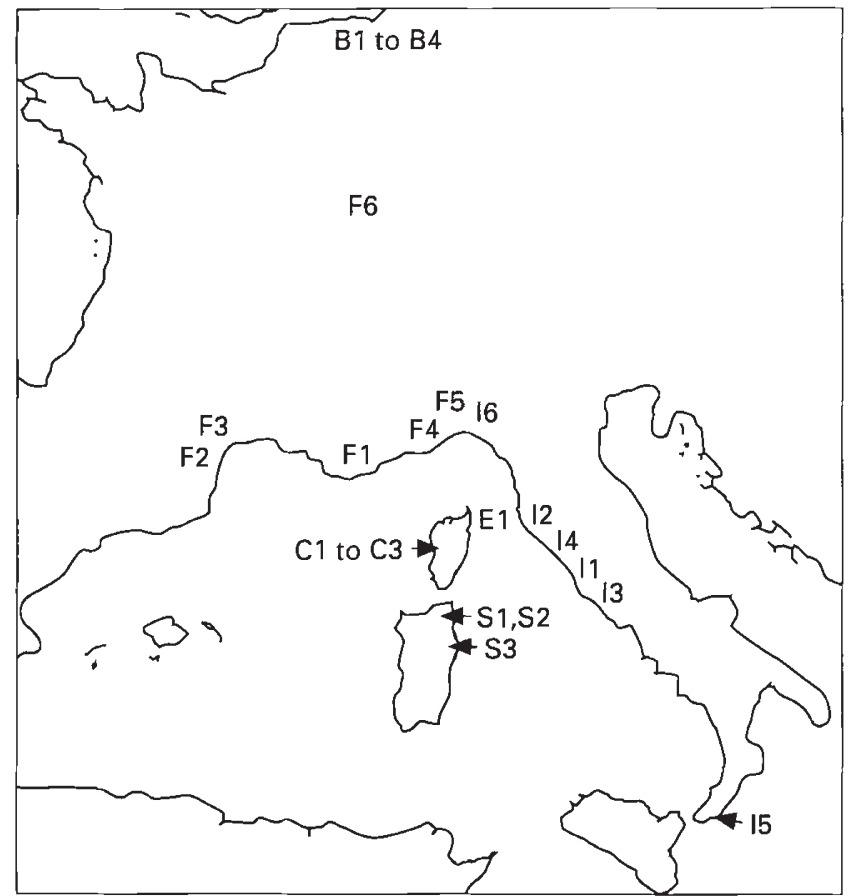

Fig. 1 Geographical distribution of the samples of Apodemus sylvaticus.

sharing a common composite restriction pattern were considered to belong to the same mtDNA matrilineal clone.

The proportion of shared fragments between two individuals was calculated with Dice's index as:

$F=2 N_{\mathrm{xy}} /\left(N_{\mathrm{x}}+N_{\mathrm{y}}\right)$,

where $N_{\mathrm{x}}$ and $N_{\mathrm{y}}$ are the numbers of fragments in individuals $\mathrm{X}$ and $\mathrm{Y}$, and $N_{\mathrm{xy}}$ is the number of fragments shared by $\mathrm{X}$ and $\mathrm{Y}$. Values of Dice's index were converted to estimate the nucleotide sequence divergence, $p$, according to Nei \& $\mathrm{Li}$ (1979). Dendrograms were constructed from matrices of p-values by the unweighted pair group method (UPGMA; Sokal \& Sneath, 1963).

\section{Results}

\section{Electrophoretic analysis of allozyme variation}

A total of 191 animals representing 14 populations have been studied electrophoretically. Fourteen of 33 loci were monomorphic and fixed for the same allele in all of the 14 populations analysed: $L d h-1$, Mdh-1, Mdh-2, Idh-2, G6pdh, G3pdh, Ipo-2, Hk-1, Ck, Ap-2, Ap-3, Lap, Acph and Aldo. The other loci were polymorphic.

Four alleles were characteristic of some Corsican animals: Ldh-2 (92), Adk (90), Fum (96) and Got-2
(92); the last was also found in the sample from Elba. In spite of these peculiarities, these mice remain very close to the peninsular Italian ones. Indeed, they share with the latter, the $N p$ (104) allele which has been found exclusively among the Italian woodmice.

Levels of genetic variation within samples are given in Table 2 . The overall mean observed heterozygosity $\left(H_{\mathrm{o}}\right)$ was 0.026 with values ranging from 0.016 (Sardinia) to 0.052 (Namur). The overall mean proportion of polymorphic loci $\left(P_{0.01}\right)$ was 15.6 per cent, ranging from 6.2 (Sardinia) to 34.4 per cent (Corsica). The overall mean proportion of alleles per locus $(A)$ was 1.19 , with values varying between 1.1 and 1.4. These values are consistent with those observed in other populations of the genus Apodemus (Benmehdi et al., 1980; Gemmeke, 1980; Mezhzherin, 1990; Britton-Davidian et al., 1991; Filippucci, 1992). They illustrate a great homogeneity in all the populations under study. Moreover, they belong to the range generally reported for other species of rodent (Nevo et al., 1990).

Nei's (1978) values of genetic identity $(I)$ and distance $(D)$ were calculated amongst samples for all pair-wise comparisons (Table 3). The mean genetic distance between the samples was 0.0033 , with values ranging from $0.00-0.015$. Our results are similar to those of other studies on Mediterranean A. sylvaticus populations (Benmehdi et al., 1980; Filippucci, 1987, 1992). Very small genetic distances such as these render any interpretation extremely tentative.

Table 2 Levels of genetic variation, based on 33 loci, in different populations of Apodemus sylvaticus

\begin{tabular}{lrrrrr}
\hline Samples & $\begin{array}{c}\text { No. of } \\
\text { individuals }\end{array}$ & $P_{0.01}$ & $H_{\mathrm{o}}$ & $H_{\mathrm{e}}$ & $A$ \\
\hline F1 & 7 & 12.5 & 0.018 & 0.025 & 1.1 \\
F2 & 12 & 28.1 & 0.029 & 0.028 & 1.3 \\
B1 & 9 & 9.4 & 0.018 & 0.028 & 1.1 \\
B4 & 3 & 9.4 & 0.052 & 0.040 & 1.1 \\
C1, C2, C3 & 18 & 34.4 & 0.038 & 0.059 & 1.4 \\
S1, S3 & 8 & 6.2 & 0.016 & 0.014 & 1.1 \\
E1 & 13 & 12.5 & 0.026 & 0.027 & 1.2 \\
I1 & 21 & 25 & 0.030 & 0.032 & 1.3 \\
I4 & 91 & 25 & 0.020 & 0.024 & 1.4 \\
I2 & 4 & 15.6 & 0.039 & 0.048 & 1.2 \\
I3 & 6 & 9.4 & 0.031 & 0.028 & 1.1 \\
\hline
\end{tabular}

$P_{0.01}=$ proportion of polymorphic loci using a $1 \%$ criterion; $H_{\mathrm{o}}=$ observed heterozygosity; $H_{3}=$ expected heterozygosity; $A=$ average number of alleles per locus. 
Table 3 Values of Nei's (1978) genetic identity ( $I$, above the diagonal) and distance $(D$, below the diagonal) between the samples of Apodemus sylvaticus

\begin{tabular}{lccccccccccr}
\hline Samples & F1 & F2 & B1 & B4 & C1, C2, C3 & S1, S3 & E1 & I1 & I4 & I2 & I3 \\
\hline F1 & - & 1.000 & 1.000 & 1.000 & 0.996 & 0.998 & 0.997 & 1.000 & 0.998 & 0.997 & 1.000 \\
F2 & 0.000 & - & 0.999 & 0.996 & 0.996 & 0.999 & 0.998 & 0.999 & 1.000 & 0.998 & 0.999 \\
B1 & 0.000 & 0.001 & - & 1.000 & 0.996 & 0.997 & 0.998 & 1.000 & 0.997 & 1.000 & 1.000 \\
B4 & 0.000 & 0.004 & 0.000 & - & 0.994 & 0.993 & 0.993 & 0.999 & 0.994 & 0.998 & 1.000 \\
C1, C2, C3 & 0.004 & 0.004 & 0.004 & 0.006 & - & 0.998 & 0.999 & 0.997 & 0.996 & 0.998 & 0.996 \\
S1, S3 & 0.002 & 0.001 & 0.003 & 0.007 & 0.002 & - & 1.000 & 0.998 & 0.999 & 0.997 & 0.998 \\
E1 & 0.003 & 0.002 & 0.002 & 0.007 & 0.001 & 0.000 & - & 0.998 & 0.998 & 1.000 & 0.998 \\
I1 & 0.000 & 0.001 & 0.000 & 0.001 & 0.003 & 0.002 & 0.002 & - & 0.998 & 0.999 & 1.000 \\
I4 & 0.002 & 0.000 & 0.003 & 0.006 & 0.004 & 0.001 & 0.002 & 0.002 & $\overline{-}$ & 0.998 & 0.998 \\
I2 & 0.003 & 0.002 & 0.000 & 0.002 & 0.002 & 0.003 & 0.000 & 0.001 & 0.002 & - & 1.000 \\
I3 & 0.000 & 0.001 & 0.000 & 0.000 & 0.004 & 0.002 & 0.002 & 0.000 & 0.002 & 0.000 & - \\
\hline
\end{tabular}

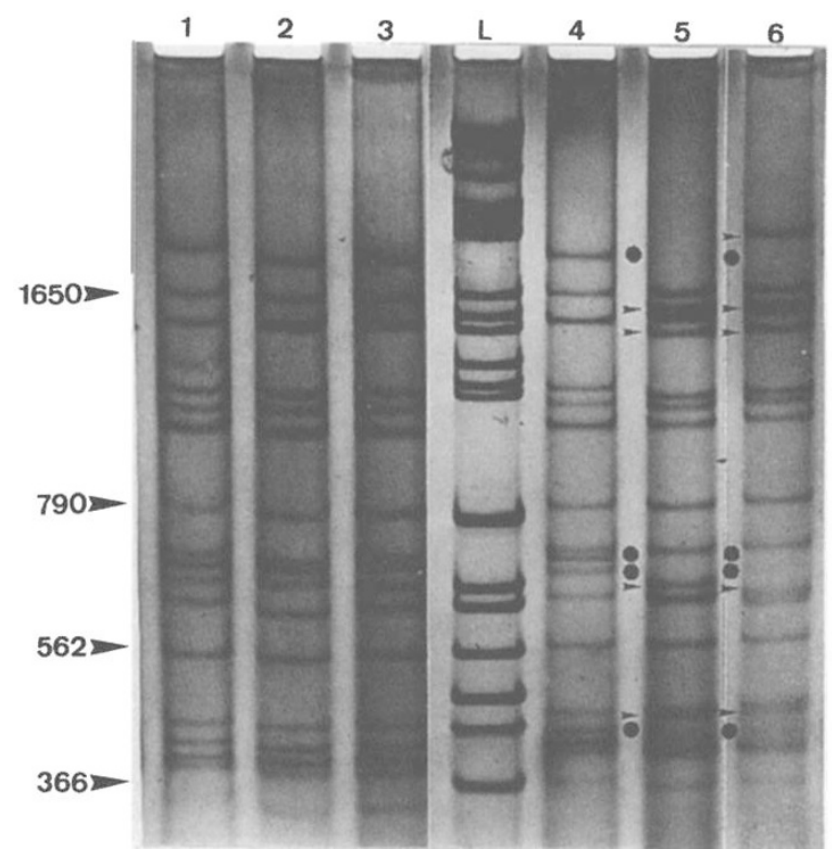

Fig. 2 Representative examples of fragment patterns after HaeIII restriction endonuclease digestion of Apodemus sylvaticus mtDNA from: $1, \mathrm{~S} 1 ; 2, \mathrm{I} 1 ; 3, \mathrm{E} 1 ; 4, \mathrm{C} 1 ; 5, \mathrm{~F} 3 ; 6$, B3. The lane marked $L$ contains Lambda DNA digested with restriction endonuclease $B g l \mathrm{I}$ to produce fragment size markers, the sizes of which are indicated on the left. The fragment sizes (in bp) of the four Tyrrhenian animals are: $2000,1700,1475,1475,1200,1115,1050,840,740$, $730,715,640,590,480,450,410,400$ and 370 . The dots show the fragments which are lacking in the western European animals (F3 and B3), and the arrows indicate the fragments which are lacking in the Tyrrhenian ones.

\section{mtDNA restriction pattern analysis}

A total of 133 animals representing 21 populations have been analysed. Using two restriction endonucleases, we obtained a total of 42-46 mtDNA frag-

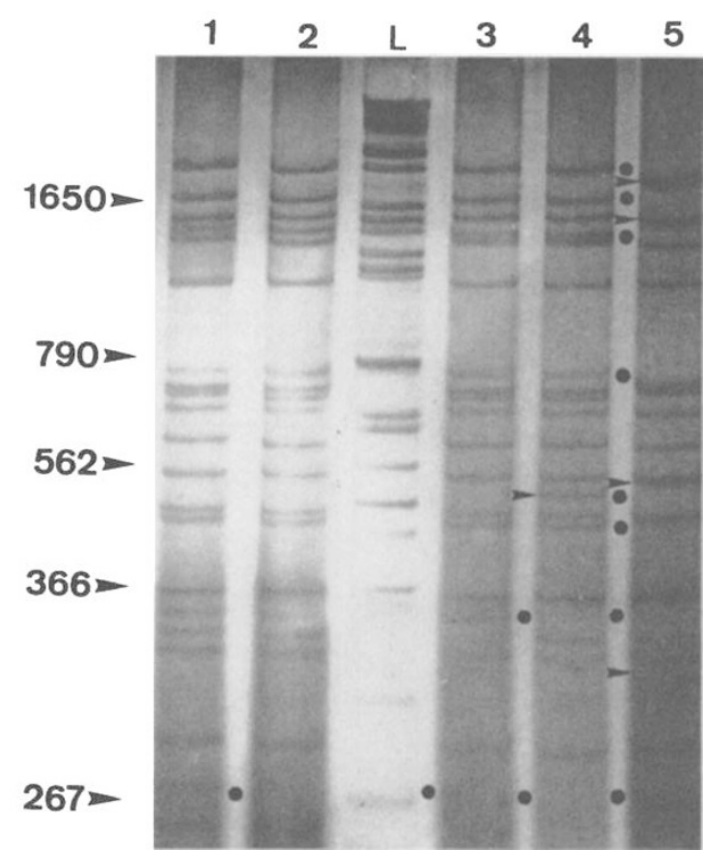

Fig. 3 Representative examples of fragment patterns after RsaI restriction endonuclease digestion of Apodemus sylvaticus mtDNA from: $1, \mathrm{I} 1 ; 2, \mathrm{I} 1 ; 3, \mathrm{C} 1 ; 4, \mathrm{C} 2 ; 5$, F3. The lane marked $\mathrm{L}$ contains Lambda DNA digested with restriction endonuclease $B g l$ I to produce fragment size markers, the sizes of which are indicated at the left. The fragment sizes (in bp) of the reference animal (I1 in lane 1) are: $1925,1700,1425,1220,1180,1000,730,700,700$, $670,590,530,475,455,350,315,300,285,235,235,215$, 195, 140 and 135. Comparing the other lanes with the reference animal, a dot appears in front of a fragment which is lacking and an arrow in front of a new one.

ments for each animal. This number of restriction fragments seems quite adequate to obtain a good estimation of the divergence amongst the samples as far as nucleotide sequences are concerned (Ferris et 
$a l ., 1983 \mathrm{a}, \mathrm{b})$. The tables of the different fragment sizes obtained after digestion by HaeIII and RsaI are available upon request from the first author.

We did not observe obvious differences in the total length of the mtDNA as recalculated after interpretation of each restriction pattern, a potential problem raised by Tegelström \& Jaarola (1989). We obtained 57 different clones from the animals examined. Some of the most representative are illustrated in Figs 2 and 3. The greatest sequence divergence

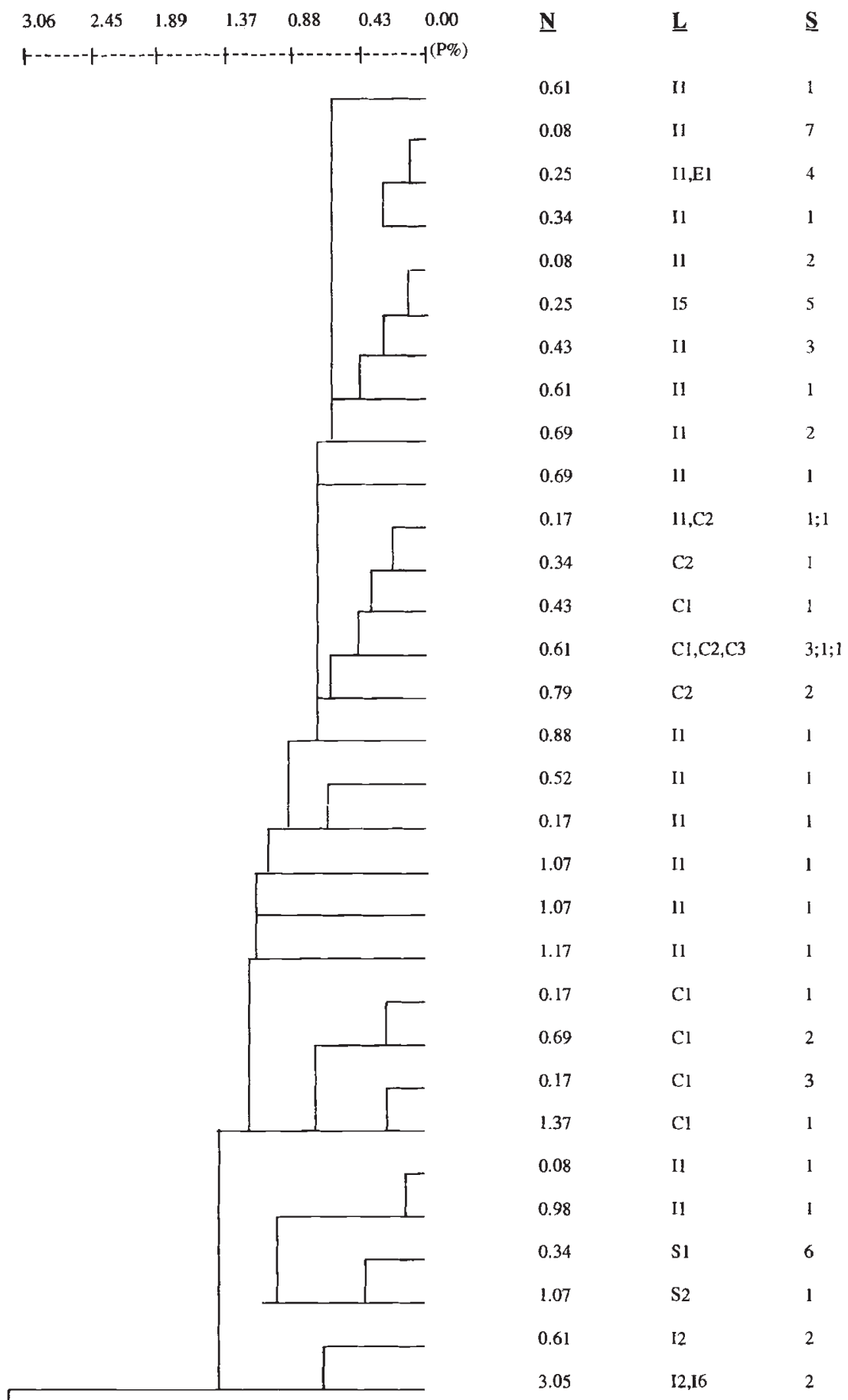

Fig. 4 UPGMA cluster analysis dendrogram of the $57 \mathrm{mtDNA}$-identified clones. Nucleotide sequence divergence is calculated according to $\mathrm{Nei}$ \& $\mathrm{Li}$ (1979). N, level of the node in nucleotide sequence divergence units; L, locality (see Table 1); S, sample.

(C) The Genetical Society of Great Britain, Heredity, 76, 267-277. 
Fig. 4 continued.

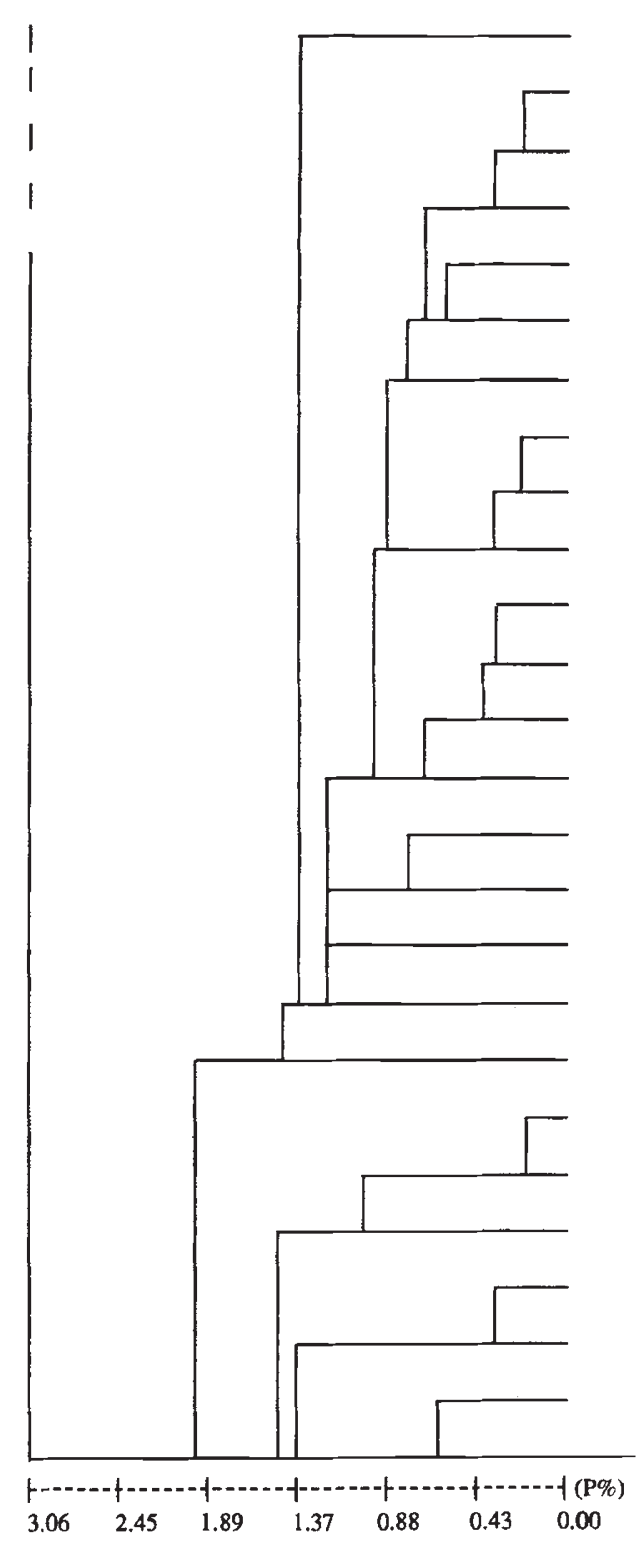

\begin{tabular}{|c|c|c|}
\hline 1.37 & F1 & 1 \\
\hline 0.17 & F2 & 1 \\
\hline 0.34 & F1 & 1 \\
\hline 0.39 & F2 & 1 \\
\hline 0.52 & F1 & 1 \\
\hline 0.79 & F1 & 3 \\
\hline 0.88 & F2 & 2 \\
\hline 0.17 & F3 & 4 \\
\hline 0.34 & F7 & 2 \\
\hline 0.98 & F3 & 4 \\
\hline 0.34 & $\mathrm{~B} 1, \mathrm{~B} 3, \mathrm{~B} 4, \mathrm{~F} 6$ & $5 ; 3 ; 2 ; 7$ \\
\hline 0.43 & B2 & 3 \\
\hline 0.69 & B4 & 3 \\
\hline 1.27 & B3 & 2 \\
\hline 0.79 & F6 & 1 \\
\hline 1.27 & F6 & 1 \\
\hline 1.27 & F1 & 1 \\
\hline 1.47 & F2 & 1 \\
\hline 2.00 & F2 & 1 \\
\hline 0.17 & F5 & 1 \\
\hline 1.07 & F5 & 2 \\
\hline 1.47 & F5 & 2 \\
\hline 0.34 & F5 & 1 \\
\hline 1.37 & F4 & 4 \\
\hline \multirow[t]{2}{*}{0.61} & F6 & 1 \\
\hline & F6 & 1 \\
\hline
\end{tabular}

found between the clones was 4.50 per cent $(F=0.59)$. The UPGMA dendrogram (Fig. 4) shows that these clones were well separated into two very distinct clusters. The first cluster collected all the Tyrrhenian animals, i.e. those from peninsular Italy including the Piedmont and from the three islands, Elba, Sardinia and Corsica. The second one included all the animals trapped in Belgium and in different regions of France, including the Pyrenees and the western Alps. The mean level of the sequence divergence of nucleotides between these two groups is quite high: $p=3.05$ per cent whereas the intragroup level is very low: 0.36 and 0.79 per cent, respectively, in the Tyrrhenian and in the French groups. The latter values are of the same order of magnitude as those observed using the same technique in woodmouse populations of northern Europe $(p<1$ per cent) (Tegelström \& Jaarola, 1989; Van Rompaey, 1989) and in other rodent species (Brown \& Simpson, 1981; Ferris et al., 1983a,b).

\section{Discussion}

The enzymatic analysis shows a great homogeneity between all the populations studied, except for some 
animals from Corsica and Elba which have some particular alleles. This technique does not reveal sufficient variation upon which to draw conclusions. On the contrary, the variation observed in the mtDNA restriction patterns allows inferences to be made on the following points.

The existence of at least two woodmouse groups in the western Mediterranean basin

The mean level of sequence divergence of nucleotides in the 'French' group is of the same order of magnitude as the value observed in the British Isles and in northern Europe including Belgium $(p<1$ per cent) (Tegelström \& Jaarola, 1989; Van Rompaey, 1989). We can thus assume that our 'French' group is part of a bigger 'North-western' group corresponding to the nominal subspecies of $A$. sylvaticus and extending towards Scandinavia. As we trapped many animals in the Mediterranean (Cap Lardier, Banyuls/Mer) and in the Pyrenees (Massane) biomes, we can no longer accept the opinion of Saint Girons (1973) about the presence of $A$. sylvaticus dichrurus (Rafinesque, 1814) in southern France and of $A$. sylvaticus callipides (Cabrera, 1907) in the Pyrenean region. She is also probably wrong in writing that $A$. sylvaticus clanceyi has been observed in the French southern Alps.

The great homogeneity all over continental western Europe has to be checked in the Iberian peninsula. This could confirm a postglacial recolonization of western Europe from a refuge population which would have survived close to the pre-Pyrenean border of the Mediterranean sea or on the southern side of these mountains.

As far as the Tyrrhenian group is concerned, the level of nucleotide divergence from the Northwestern group is so high ( $>3$ per cent) that a subspecific status of that group seems quite appropriate. Indeed, Ferris et al. $(1983 a, b)$ consider that a level of 4 per cent divergence could lead to the distinction of different subspecies. Bearing in mind the taxonomic laws of priority, the Tyrrhenian woodmouse should be named $A$. sylvaticus milleri de Beaux, 1926 and A. sylvaticus clanceyi Harrison, 1947 considered as synonym. In the same way, we could consider $A$. sylvaticus ilvanus Kahmann and Niethammer, 1971 also as a synonym. Indeed, gigantism appears to be a general response of small species exposed to insularity conditions, particularly on very small islands: e.g. Apodemus on Elba (Kahmann \& Niethammer, 1971), on Pantelleria (Felten \& Storch, 1970), Porquerolles (Libois \& Fons, 1990) and Ibiza (Alcover \& Gosalbez, 1988) and Crocidura suaveolens on Corsica, Yeu, Ouessant and Sein (Saint Girons, 1973).

Nevertheless, considering that (i) our mtDNA analysis was made on just one specimen, (ii) the morphological differentiation of this population is particularly important and (iii) morphological and molecular evolution appear to proceed independently in mammals (Schnell \& Selander, 1981), we have to be careful on this point.

Our interpretation agrees with the results of Gemmeke et al. (1987) which emphasize the contrast in the transferin structure between woodmice living in Spain, France, Switzerland, Germany and even Tunisia on one hand and those living in Italy, Sardinia, eastern Austria and Slovenia on the other.

\section{The Alps as a biogeographical barrier}

The Alps are well known as a biogeographical barrier for many animals, for example the small mammal species Talpa caeca, Crocidura leucodon, Pitymys savii, Pitymys duodecimcostatus, Clethrionomys glareolus, Arvicola sapidus and Mus spretus, several bird species such as Dryocopus martius (the black woodpecker), Phylloscopus trochilus (the willow warbler), Sylvia curruca (the lesser whitethroat) and Passer domesticus italiae (the Italian house sparrow), and for 20 species of reptiles and amphibians (Orsini, 1990). For ground dwelling species, the obstacle is obvious: high summits with glaciers in the north, and dry, bare hills falling directly into the sea on the western edge. This barrier also appears to be very efficient for the highly adaptable woodmouse. Indeed, all the animals trapped on the western edge of the Alps (Estérel, La Penne) display a clear North-western mtDNA restriction pattern whereas that of the Piedmont (Cuneo) displays a typical Tyrrhenian one. This raises the question of exactly when these two woodmouse strains parted from each other.

From the enzymatic study, the separation could be about 15000 years old, assuming a rate of change of one distance unit per 0.7-1.5 Myr (an estimate usually employed in protein-clock calibration for small mammals: Tegelström \& Jaarola, 1989; Avise \& Aquadro, 1982), but this is likely to be very inaccurate given the low values of $D$. The mtDNA study leads, however, to longer time estimates. Assuming a 2-4 per cent rate of mtDNA-sequence divergence/ myr (Wilson et al., 1985), the divergence between the Tyrrhenian and the North-western groups would be 730000-1 460000 years old. To explain similar discrepancies between the two evaluation methods, Tegelström \& Jaarola (1989) and Van Rompaey 
(1989) formulated the following hypotheses: (i) the rate of protein evolution is much slower than usually postulated, (ii) the rate of mtDNA divergence is much faster than previously assumed, (iii) mtDNA divergence predates nuclear divergence and (iv) there is nuclear gene flow between populations after the separation event.

These four hypotheses are not mutually exclusive. However, Van Rompaey's (1989) opinion is that the first two hypotheses are probably more appropriate to explain such differences: the calibration rate could be a major source of error and the 'technique' is still strongly debated (Nei, 1987). In this way, Catzeflis et al. (1992) have discovered that the calibration rate of the mtDNA molecular clock could be different between one mammal family and another. For example, the mtDNA of muroid rodents could evolve at least three times faster than that of primates and other mammals. Catzeflis et al. (1987) concluded that 'There is not a single, global DNA clock ticking at the same average rate in all mammals; rather, the rate of genomic evolution in each group must be determined separately by calibrating numbers of nucleotides changes with absolute divergence dates that are derived from fossils or vicariant events.

\section{The origin of the woodmouse settlement in the Tyrrhenian islands}

The Italian origin of the Tyrrhenian islands woodmice is taken for granted. As a result of the enzymatic analysis, we can suggest the route Etruria $\rightarrow$ Elba $\rightarrow$ Corsica as the most probable one. Having in mind the anthropogenic origin of these animals (Sanges \& Alcover, 1980; Vigne, 1983), this hypothesis agrees with those of archaeologists (Klein Hoffmeiyer et al., 1986) who observed the same type of human Neolithic culture in continental Italy, Elba and Corsica. That seems to indicate that there were some relationships between the Neolithic human populations established on these two islands and on peninsular Italy, offering colonization opportunities for the woodmouse.

The origin of the Sardinian woodmice is less obvious: archaezoologists (Cherry, 1990; Vigne, 1990) share the opinion that the colonization of Sardinia took place from Italy through Corsica. Our molecular results, however, show that animals of the two islands differ; the characteristic alleles of Corsican and Elban Apodemus are completely absent in Sardinian mice. Sardinia was thus probably invaded directly from Italy.

\section{Conclusions}

To sum up, the present study shows clearly that the taxonomy of the woodmouse on the western Mediterranean basin has to be reconsidered at the subspecific level.

1 From the Pyrenees to Belgium and even to Scandinavia and the mainland of the U.K. and Ireland (see Tegelström \& Jaarola, 1989 \& Van Rompaey, 1989), woodmice share very similar mtDNA restriction patterns. Consequently, they must belong to the same subspecies, nominally $A$. s. sylvaticus.

2 The populations of the Tyrrhenian islands and of peninsular Italy have a common origin and differ from the North-western subspecies. Archaezoological findings strongly suggest that the woodmouse was recently introduced to Corsica by man. The Sardinian colonization was also anthropogenic. Therefore, we can logically combine all these populations in the same subspecies, A. s. milleri, A. $s$. clanceyi becoming synonymous.

3 These Tyrrhenian mice are well isolated from those living on the western edge of the Alpine chain, either in the Mediterranean biome or in the more temperate zones including the eastern Pyrenean beech forest (Massane).

4 Until the validity of $A$. s. callipides is checked, we suggest that the extent of its geographical range in France is restricted to the western and possibly the central Pyrenees.

\section{Acknowledgements}

Thanks are expressed to friends and colleagues who helped us in trapping and keeping the animals in captivity: Sandrina Kinet, Etienne Delooz, François Legros, Daniel Nibes, Daniel Sirugue, Jean-Pierre Clara, Mr and Mrs Michaux, Céline Maurois, Alain Lecloux and Jacques Ninane. This research was supported by an IRSIA fellowship to J. R. Michaux and by a FRFC grant (no. 2.4547.89) to Prof. J. C. Ruwet.

\section{References}

AlCOVER, J. A. AND Gosalbez, J. 1988. Estudio comparado de la fauna de micromamiferos de las Islas Baleares y Pitiusas. Bull. Ecol., 19, 2-3, 321-328.

AVISE, J. C. AND AQUADRo, C. F. 1982. A comparative summary of genetic distances in the vertebrates. In: Hecht, M. K., Wallace, B. and Prance, G. T. (eds) Evolutionary Biology, vol. 15, pp. 151-185. Plenum Press, New York.

BENMEHDI, F., BRITTON-DAVIDIAN, J. AND THALER, L. 1980. 
Premier apport de la génétique biochimique des populations à la systématique des mulots de France continentale et de Corse. Biochem. Syst. Ecol., 8, 309-315.

BERRY, R. J. 1973. Chance and change in British Longtailed field mice (Apodemus sylvaticus). J. Zool. Lond., 170, 351-363.

BERRY, R. J., EVANS, D. AND SENNIT, J. 1967. The relationships and ecology of Apodemus sylvaticus from the small isles of the Inner Hebrides, Scotland. J. Zool., Lond., 152, 333-346.

BRITTON-DAVIDIAN, J., VAHDATI, M., BENMEHDI, F. ET AL. 1991. Genetic differenciation in four species of Apodemus from Southern Europe: A. sylvaticus, A. flavicollis, $A$ agrarius and $A$. mystacinus (Muridae, Rodentia). $Z$. Säugetierk., 56, 25-33.

BROWN, G. AND SIMPSON, M. 1981. Intra-and interspecific variation of the mitochondrial genome in Rattus rattus and Rattus norvegicus: restriction enzyme analysis of variant mitochondrial DNA molecules and their evolutionary relationships. Genetics, 97, 125-143.

BROWN, w. M. 1980. Polymorphism in mitochondrial DNA of humans as revealed by restriction endonuclease analysis. Proc. Nat. Acad. Sci. U.S.A., 76, 1967-1971.

CATZEFlis, F. M., AGUilAR, J.-P. AND JAEGER, J.-J. 1992. Muroid rodents: phylogeny and evolution. Trends Ecol. Evol., 7, 122-125.

CATZEFLIS, F. M., SHELDON, F. H., AHLQUIST, J. E. AND SIBLEY, C. G. 1987. DNA-DNA hybridization evidence of the rapid rate of Muroid rodent DNA evolution. Mol. Biol. Evol., 4, 242-253.

Cherry, J. F. 1990. The first colonization of the Mediterranean Islands: a review of recent research. J. Medit. Archaeol., 3, 145-221.

DARVICHE, D. 1978. Approche Morphologique et Biométrique de la Biosystématique à la Lumière de la Génétique Biochimique des Populations. Application aux Genres Mus et Apodemus (Mammalia, Rodentia). Third cycle thesis, University of Montpellier.

ENGEL, W., VOGEL, W., VOICULESCU, 1., ROPERS, H.-H., ZENZES, M.-T. AND BENDER, K. 1973. Cytogenetic and biochemical differences between Apodemus sylvaticus and Apodemus flavicollis, possibly responsible for the failure to interbreed. Comp. Biochem. Physiol., 44B, 1165-1173.

FELTEN, H. AND STORCH, G. 1970. Kleinsäuger von den italienischen Mittelmeer-Inseln Pantelleria und Lampedusa. Senckenberg Biol., 51, 159-173.

FERRIS, S. D., SAGE, R. D., HUANG, C. M., NIELSEN, J. T., RITTE, U. AND WILSON, A. C. 1983a. Flow of mitochondrial DNA across a species boundary. Proc. Natl. Acad. Sci. U.S.A., 80, 2290-2294.

FERRIS, S. D., SAGE, R. D., PRAGER, E. M., RITTE, U. AND WILSON, A.C 1983b. Mitochondrial DNA evolution in mice. Genetics, 105, 681-721.

FilippuCCI, M. G. 1987. Evoluzione Cromosomica e Genica in Micromammiferi dell'Area Mediterranea (Talpidae, Gliridae, Muridae). Ph.D. Thesis, University of Padova, Italy.

FILIPPUCCI, M. G. 1992. Allozyme variation and divergence among European, Middle Eastern and North African species of the genus Apodemus (Rodentia, Muridae). Israel J. Zool., 38, 193-218.

FILIPPUCCI, M. G., CRISTALDI, M., TIZI, L. AND CONTOLI, L. 1984. Dati morfologici e morfometrici in populazioni di Apodemus (Sylvaemus) dell'Italia centro-meridionale determinati elettroforeticamente. In: Contoli, L., Cristaldi, M., Filippucci, M. G., Tizi, L. and VignaTaglianti, A (eds) Recenti acquisizioni sul genere Apodemus in Italia. Supplemento di Biologia della Selvaggina, vol. 9, pp. 85-126. Istituto di Biologia della Selvaggina Bologna.

Flowerdew, J. R. 1991. Woodmouse, Apodemus sylvaticus. In: Corbet, G. B. and Harris, S (eds) The Handbook of British Mammals, 3rd edn, pp. 220-229. Blackwell Scientific Publications, Oxford.

FONS, R. LIBOIS, R. M. AND SAINT GIRONS, M. C. 1980. Les micromammifères dans le département des PyrénéesOrientales. Essai de répartition altitudinale en liaison avec les étages de végétation. Vie et Milieu, 30, 285-299.

gemmeke, H. 1980. Proteinvariation und Taxonomie in der Gattung Apodemus (Mammalia, Rodentia). $Z$. Säugetierk., 45, 348-365.

GEMMEKE, H., RADKTE, M. AND NiETHAMMER, J. 1987. Zur innerartlichen Proteinvariation bei der Waldmaus (Apodemus sylvaticus). Z. Säugetierk., 52, 242-247.

GlaGiA, E. 1985. Karyotype study of the genus Apodemus (Kaup, 1829) populations from the Balkan peninsula. Acta Vet. Beograd, 35, 289-298.

GuillemetTe, J. G. AND LEWIS, P. N. 1983. Detection of subnanogram quantities of DNA and RNA on native and denaturing polyacrylamide and agarose gels by silver staining. Electrophoresis, 4, 92-94.

KAHMANN, H. 1969. Die Alveolenmuster der Oberkiefzahnreihe der Waldmaus, Hausratte und Hausmaus aus Populationen der grossen tyrrhenischen Inseln. Z. Säugetierk., 34, 164-183.

KAHMANN, H. AND NiETHAMMER, J. 1971. Die Waldmaus (Apodemus sylvaticus) auf der Insel Elba. Senckenberg Biol., 52, 381-392.

KLEIN HOFFMEIYER, G., MARTINI, F., SANGES, M., SONDAAR, P. Y. AND uBjegA, A. 1986. La Fine del Pleistocene Nella Grotta Corbeddu in Sardegna: Fossili Umani, Aspetti Paleontologici e Cultura Materiale. Rivista di Scienze Preistoriche, Rome.

KOWALSKI, K. AND RZEBIK-KOWALSKA, B. 1991. Mammals of Algeria. Ossolineum, Wroclaw.

LANSMAN, R. A., SHADE, R. O., SHAPIRA, J. F. AND AVISE, J. C. 1981. The use of restriction endonucleases to measure mitochondrial DNA sequence relatedness in natural populations. III. Techniques and potential applications. J. Mol. Evol., 17, 214-226.

LIBOIS, R. M. AND FONS, R. 1990. Le mulot des îles d'Hyères: un cas de gigantisme insulaire. Vie et Milieu, 40, 217-222.

LiBoIS, R. M., FONS, R. AND BORDENAVE, D. 1993. Mediterranean small mammals and insular syndrome: Biometrical study of the long-tailed field mouse (Apodemus sylvaticus) (Rodentia-Muridae) of Corsica. 
Bonn. Zool. Beiträge, 44, 147-163.

LIBOIS, R. M., FONS, R. AND SAINT GIRONS, M. C. 1983. Le régime alimentaire de la chouette effraie, Tyto alba, dans les Pyrénées-Orientales. Étude des variations écogéographiques. Rev. Ecol. (Terre \& Vie), 37, 187-217.

mathias, M. L., RAMALhinho, M. G. 1992. A preliminary report on robertsonian karyotype variation in longtailed house mice (Mus musculus domesticus Rutty, 1772) from Madeira islands. Bocagiana, 156, 1-3.

MEZHZHER1N, I. 1. 1990. Allozyme variability and genetic divergence of long-tailed mice of subgenus Sylvaemus (Ognev and Vorobiev). Genetika, 26, 1046-1054.

MORITZ, C., DOWLING, T. E. AND BROWN, w. M. 1987. Evolution of animal mitochondrial DNA: relevance for population biology and systematics. Ann. Rev. Ecol. Syst., 18, 269-292.

NASCETTI, G. AND FILIPPUCCl, M. G. 1984. Variabilita e divergenza genetica in popolazioni italiane di Apodemus sylvaticus e Apodemus flavicollis (Rodentia, Muridae). In: Contoli, L., Cristaldi, M., Filippucci, M. G., Tizi, L. and Vigna-Taglianti, A. (eds) Recenti Acquisizioni sul Genere Apodemus in Italia. Supplemento alle Ricerche di Biologia della Selvaggina, vol. 9, pp. 75-83. Istituto di Biologia della Selvaggina, Bologne.

NEI, M. 1978. Estimation of average heterozygosity and genetic distance from a small number of individuals. Genetics, 89, 583-590.

NEI, M. 1987. Molecular Evolutionary Genetics. Columbia University Press, New York.

NEI, M. AND LI, w.-H. 1979. Mathematical model for studying genetic variation in terms of restriction endonucleases. Proc. Natl. Acad. Sci. U.S.A., 76, 5269-5273.

NEVO, E. FILIPPUCCI, M. G. AND BEILES, A. 1990. Diversity and its ecological correlates in nature: comparisons between subterranean, fossorial and aboveground small mammals. In: Nevo, E. and Reig, O. A (eds) Evolution of Subterranean Mammals at the Organismal and Molecular Levels, pp. 347-366. Wiley-Liss, New York.

ORsIN1, P. 1990. Richesse, diversité et abondance de quelques peuplements de micromammifères des AlpesMaritimes. Vie et Milieu, 40, 229-233.

PALVA, T. K. AND PALVA, T. 1985. Rapid isolation of animal mitochondrial DNA by alkaline extraction. FEBS Lett., 192, 267-270.

PASQUIER, L. 1974. Dynamique Évolutive d'un Sous-Genre de Muridae: Apodemus sylvaticus (Sylvaemus). Étude Biométrique des Caractères Dentaires de Populations Fossiles et Actuelles d'Europe Occidentale. Ph.D Thesis, University of Montpellier.

SAID, K. AND BRITTON-DAVIDIAN, J. 1991. Genetic differentiation and habitat partition of Robertsonian house mouse, Mus musculus domesticus of Tunisia. J. Evol. Biol., 4, 409-428.

SAINT GIRONS, M. C. 1966. Étude du genre Apodemus Kaup, 1829 en France I. Mammalia, 30, 547-600.
SAlNT girons, M. C. 1967. Étude du genre Apodemus Kaup, 1829 en France II. Mammalia, 31, 55-100.

SAlNT Girons, M. C. 1973. Les Mammifères de France et du Benelux. Doin, Paris.

SANGES, M. AND ALCOVER, J. A. 1980. Noticia sobre la microfauna vertebrada holocenica de la grotta $\mathrm{Su}$ Guanu o Gonagosula (Oliena, Sardenya). Endins, 7, $57-62$.

SARA, M. AND CASAMENTO, G. 1995. Morphometrics of the wood mouse (Apodemus sylvaticus, Mammalia, Rodentia) in the Mediterranean. Boll. Zool., 62, 313-320.

SEARLE, J. B. 1991. A hybrid zone comprising staggered chromosomal clines in the house mouse (Mus musculus domesticus). Proc. R. Soc. B, 246, 47-52.

SCHNELL, G. D. AND SELANDER, R. K. 1981. Environmental and morphological correlates of genetic variation in mammals. In: Smith, M. H. and Joule, J (eds) Mammalian Population Genetics, pp. 60-99. University of Georgia Press, Athens, GA.

SOKAL, R. R. AND SNEATH, P. H. A. 1963. Principles of Numerical Taxonomy. W. H. Freeman, San Francisco, CA.

SWOFFORD, D. L. AND SELANDER, R. B. 1981. BIOSYS-1: a FORTRAN program for the comprehensive analysis of electrophoretic data in population genetics and systematics. J. Hered., 72, 281-283.

TEGELSTRÖM, H. 1986. Mitochondrial DNA in natural populations: An improved routine for the screening of the genetic variation based on sensitive silver staining. Electrophoresis, 7, 226-229.

TEGELSTRÖM, H. AND JAAROLA, M. 1989. Genetic divergence in mitochondrial DNA between the Wood mouse (Apodemus sylvaticus) and the Yellow necked mouse (A. flavicollis). Hereditas, 111, 49-60.

TOSCHI, A. AND LANZA, B. 1965. Fauna d'Italia. Calderini, Bologna.

VAN ROMPAEY, J. 1989. Variatie en Differentiatie van Mitochondrial DNA in Clethrionomys glareolus (Schreber, 1780), Apodemus sylvaticus (Linnaeus, 1758) en Apodemus flavicollis (Melchior, 1834) (Mammalia, Rodentia) in West Europa. Ph.D Thesis. University of Antwerp.

VIGNE, J. D. 1983. Le remplacement des faunes de petits mammifères en Corse, lors de l'arrivée de l'homme. $C$. R. Soc. Biogéogr., 59, 41-51.

VIGNE, J. D. 1990. Biogeographical history of the mammals of Corsica (and Sardinia) since the final pleistocene. In: Atti dei Convegni Lincei, International Symposium on Biogeographical Aspects of Insularity, pp. 369-392, Academia Nazionale dei Lincei, Rome.

VON LEHMANN, E. AND SCHAEFER, H. E. 1976. Kreuzungsergebnisse mit Waldmäusen (Apodemus) der Insel Sizilien. Saugertierk. Mitt., 24, 180-184.

WILSON, A. C., CANN, R. L., CARR, S. M. ET AL. 1985. Mitochondrial DNA and two perspectives on evolutionary genetics. Biol. J. Linn. Soc., 26, 375-400. 